\title{
Assessing downgrading of esophageal adenocarcinoma after neoadjuvant chemotherapy: a case report
}

\author{
Indrasto Histopaedianto ${ }^{1}$, Adeodatus Yuda Handaya ${ }^{2 *}$, Hendro Wartatmo ${ }^{2}$ \\ ${ }^{1}$ Trainee in Digestive Surgery, ${ }^{2}$ Digestive Surgery Division, Department of Surgery, Faculty \\ of Medicine/Dr. Sardjito General Hospital, Universitas Gadjah Mada Yogyakarta, Indonesia
}

DOI: http://dx.doi.org/10.19106/JMedSci004901201706

\begin{abstract}
Esophageal carcinoma, squamous cell carcinoma, and adenocarcinoma, are a deadly serious malignancy. The delay in diagnosis due to the lack of specific symptoms in the early stages of the disease and the nature of esophageal cancer is very aggressive lead to a poor prognosis with a survival rate of small. Current management of esophageal cancer is recommended multimodal approach in the form of neoadjuvant chemotherapy or combined radiochemotherapy (CRT) and with surgery. In this article, multimodality treatment using chemotherapy and surgery on esophageal adenocarcinoma was reported. A 52-year-old male presented with a total obstruction of the esophagus and was planned to perform temporary gastrostomy for chemotherapy preparation. Gastrostomy found a solid and fixed tumor located in the gastroesophageal junction, with the size of $7 \times 6 \times$ $5 \mathrm{~cm}^{3}$. He underwent a chemotherapy using the regimen of 8 cycles paclitaxel without radiotherapy due to the long queue of radiotherapy schedule. After chemotherapy, we reevaluated and planned to perform surgical removal of the tumor. During surgery, we found a total obstruction along with fibrosis of the esophagus but found no tumor/mass. We performed partial esophagectomy and end to side anastomosis using anastomosis end to side using the $\mathrm{CDH} 25$ circular stapler. Surgery was carried out by the thoracoabdominal approach. The patient was discharged on day 12 in a stable condition and was undergoing soft diet. We planned to evaluate the patient using Carcinoembryonic Antigen (CEA) test and Positron Emission Tomography (PET) scan. In conclusion, multimodality treatment using chemotherapy and surgery on a case of one-third distal esophageal adenocarcinoma provides good results.
\end{abstract}

\section{ABSTRAK}

Karsinoma esofagus, baik karsinoma sel skuamosa, atau adenokarsinoma merupakan keganasan yang serius dan mematikan. Lambatnya diagnosis akibat kurangnya gejala spesifik pada stadium awal penyakit dan sifat kanker esofagus yang sangat agresif menyebabkan prognosis yang buruk dengan angka ketahanan hidup yang kecil. Penatalaksanaan terkini dari kanker esofagus yang direkomendasikan adalah pendekatan multimodalit berupa neoadjuvantchemotherapy atau combined radiochemotherapy (CRT) dan dengan pembedahan. Dalam makalah ini dilaporkan penatalaksanaan multimodalitas menggunakan kemoterapi dan pembedahan terhadap adenokarsinoma esophagus. Seorang laki-laki berusia 52 tahun dikonsulkan ke bagian bedah digesti dengan diagnosa obstuksi total esofagus dan di mintakan pembuatan gastrostomi temporer untuk persiapan

Corresponding author: yudahandaya@ugm.ac.id 
kemoterapi. Saat operasi gastrostomi teraba tumor keras di gastroesophageal junction, berukuran $7 \times 6 \times 5 \mathrm{~cm}^{3}$, padat terfiksir. Kemudian dilakukan kemoterapi menggunakan paslitaksel sebanyak 8 siklus tanpa radioterapi karena antrian jadwal terlalu panjang. Setelah kemoterapi pasien di re-evaluasi dan direncanakan operasi pengangkatan tumor. Pada operasi ditemukan obstruksi total esofagus dengan jaringan fibrotik sepanjang esofagus, namun tidak ditemukan masa tumor. Selanjutnya dilakukan partial esophagectomy dan anastomosis end to side menggunakan stapler $\mathrm{CDH} 25$. Operasi dilakukan dengan pendekatan thoracoabdominal. Pasien dipulangkan hari ke 12, kondisi baik dan sudah diet lunak. Direncanakan untuk evaluasi dengan pemeriksaan Carcinoembryonic Antigen (CEA) dan Positron Emission Tomography (PET) scan. Dapat disimpulkan, penatalaksanaan multimodalitas dengan kemoterapi dan pembedahan pada kasus adenokarsinoma esofagus $1 / 3$ distal memberikan hasil baik.

Keywords: esophageal adenocarcinoma - chemotherapy - paclitaxel - esophagectomy gastrectomy

\section{INTRODUCTION}

Esophageal carcinoma and squamous cell carcinoma as well as adenocarcinoma are a serious malignancy with a poor prognosis and possibility of lethal in most cases. Esophageal carcinoma affects more than 450,000 people worldwide with a rapid incidence. ${ }^{1}$ Although the incidence is relatively rare when compared to other cancers, according to the National Cancer Institute, in 2012, in the United States about 35,781 patients with esophageal cancer were estimated and in 2015 about 16.980 new cases with 15,590 deaths were reported. ${ }^{2}$ Currently, esophageal cancer is the number 6 leading cause of cancer death worldwide because its aggressivity and poor survival rate. Although it has been many developments in the diagnosis and management, the 5-year survival rate for patients diagnosed with esophageal cancer only range between $15 \%$ $20 \%{ }^{1,3}$

Esophageal cancer generally consists of two forms, squamous cell carcinoma, and adenocarcinoma. ${ }^{1}$ Squamous cell carcinoma is the most common histologic type (95\%). The incidence of esophageal squamous cell carcinoma increases with age with a peak at the age of 70 years. The incidence of squamous cell carcinoma increased 3 -fold in dark-skinned individuals, whereas the type of adenocarcinoma is more common in fairskinned individuals. ${ }^{2,4}$

Increased incidence of esophageal cancer is associated with risk factors for these cancers. Squamous cell carcinoma of the esophagus is associated with smoking and alcohol consumption, genetic factors such as tylosis, Plummer-Vinson syndrome, and environmental exposure such as ingestion of alkali and radiotherapy. Esophageal adenocarcinoma is often grown in the distal esophagus and is associated with esophagitis, Barrett's esophagus, a metaplasia occurring in the distal gastroesophageal junction because of chronic irritation from gastroesophageal reflux disease (GERD). Obesity, whether related to their GERD or due to consumption of western-style diet is poor in vitamins, vegetables, fruit, fish, and poultry; is also a risk factor for esophageal adenocarcinoma. ${ }^{1,3,5}$

Esophageal cancer is often called the "silent cancer". Most patients are diagnosed later because of the lack of symptoms in the early stages of the disease. ${ }^{6}$ Dysphagia and weight loss occurs in about $90 \%$ cases of esophageal cancer. Other symptoms include 
odynophagia, hoarseness, cough, chest pain, melena, and residual symptoms (sequelae) of the spread of disease both locally advanced and distant spread. Approximately $75 \%$ of patients have lymph node involvement at the time of diagnosis. ${ }^{5,7}$

Esophagectomy is a primary management of early-stage esophageal cancer although its specific role in superficial cancer is still being debated ever since the development of endoscopic mucosal treatment. Nowadays, the scientific evidence is enough to recommend the multimodal treatment of locally advanced cancers using the combination of neoadjuvant chemotherapy or chemoradiotherapy (CRT) followed by surgery. Some clinicians just use definitive CRT to avoid mortality due to surgery. ${ }^{8}$

We report a case of adenocarcinoma of the esophagus treated with multimodal approach of chemotherapy followed by surgery.

\section{CASE REPORT}

A-52-years-old male was consulted to the Department of Digestive Surgery of Dr. Sardjito General Hospital as an already diagnosed case of esophageal tumor. He was consulted to the department at 9 March 2015. The patient came with dysphagia as a chief complaint accompanied with nausea, vomiting, and weight loss. The onset of the symptoms started from December 2014, and gradually became more severe. At the beginning of the symptoms, he was capable of ingesting solid diet, but at the time he was consulted, he was only capable of ingesting liquid diet. During the illness, he lost his weight as much as $20 \mathrm{~kg}$, which was from 72 to $52 \mathrm{~kg}$. Physical examination did not find any abnormality. Routine laboratory test found hemoglobin level was $9.7 \mathrm{mg} / \mathrm{dL}$.

The patient had been undergoing barium meal and endoscopic examination at prior hospital. Barium meal test revealed a suspected distal esophageal tumor with a malignant tendency (FIGURE 1). Endoscopy revealed an esophageal tumor at $35 \mathrm{~cm}$ depth. Biopsy on the mass was conducted during endoscopy procedure. Histopathology analysis result was moderately-differentiated adenocarcinoma of the esophagus.

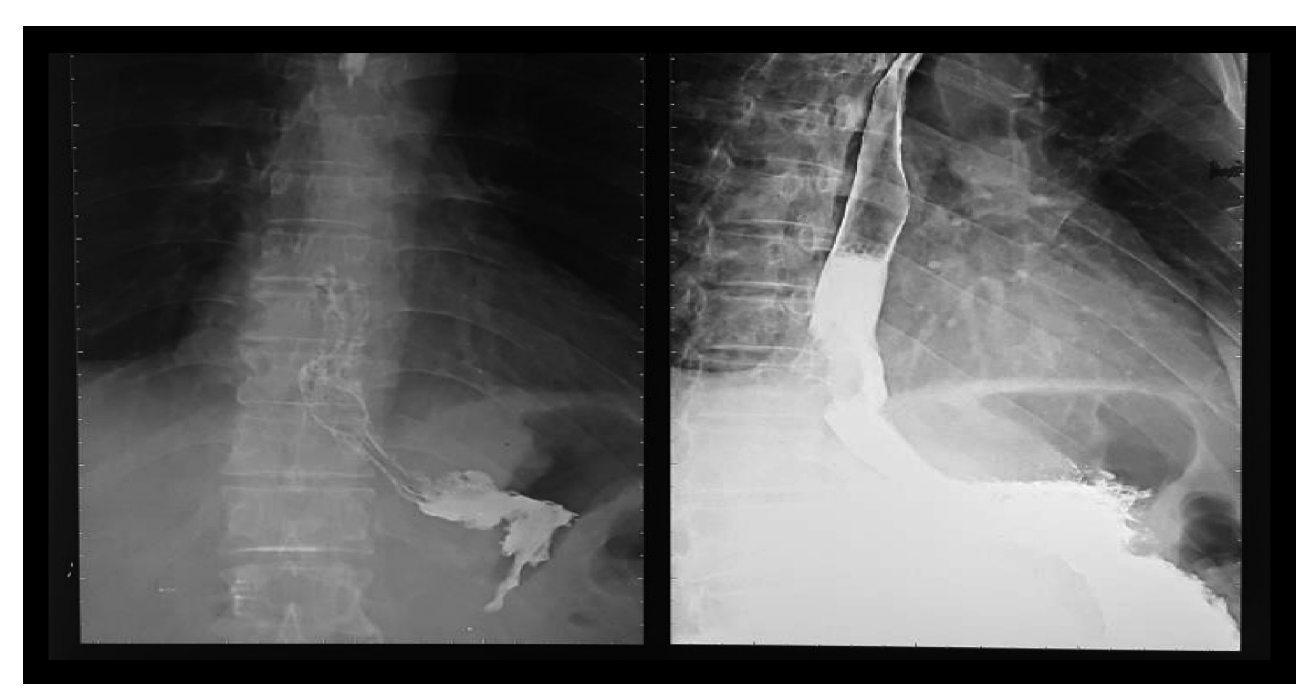

FIGURE 1. Barium meal and endoscopic result 
The patient was diagnosed as distal esophageal tumor and elected to undergo gastrostomy and exploration laparotomy on 13 March 2015. During exploration laparotomy, fixed, $7 \times 6 \times 5 \mathrm{~cm}^{3}$ esophagogastric junction mass was found. Nasogastric tube (NGT) could not pass through the tumor. Temporary gastrostomy was done and it was concluded that the esophageal tumor was unresectable and planned to undergo post-operative chemotherapy. He was consulted to Hematooncology department to receive chemotherapy. Eight cycles of paclitaxel were administered and completed at 2 November 2015. Serial CT scan evaluation was done 3 times. First
CT scan (29 May 2015) revealed narrowing of esophageal lumen, total obstruction on the level of $7^{\text {th }}$ thoracic vertebrae, and no periesophageal infiltrating mass (FIGURE 2). Second CT scan (17 September 2015) showed intraluminal mass causing total obstruction below the level of $9^{\text {th }}$ thoracic vertebrae, and no periseophageal infiltrating mass (FIGURE 3). Third CT scan (9 November 2015) revealed distal esophageal mass with $1.4 \times 1.2 \times 3.4$ $\mathrm{cm}^{3}$ dimension, smaller than prior dimension (FIGURE 4). Esophagography (19 November 2015) revealed stenosis of third distal of esophagus.

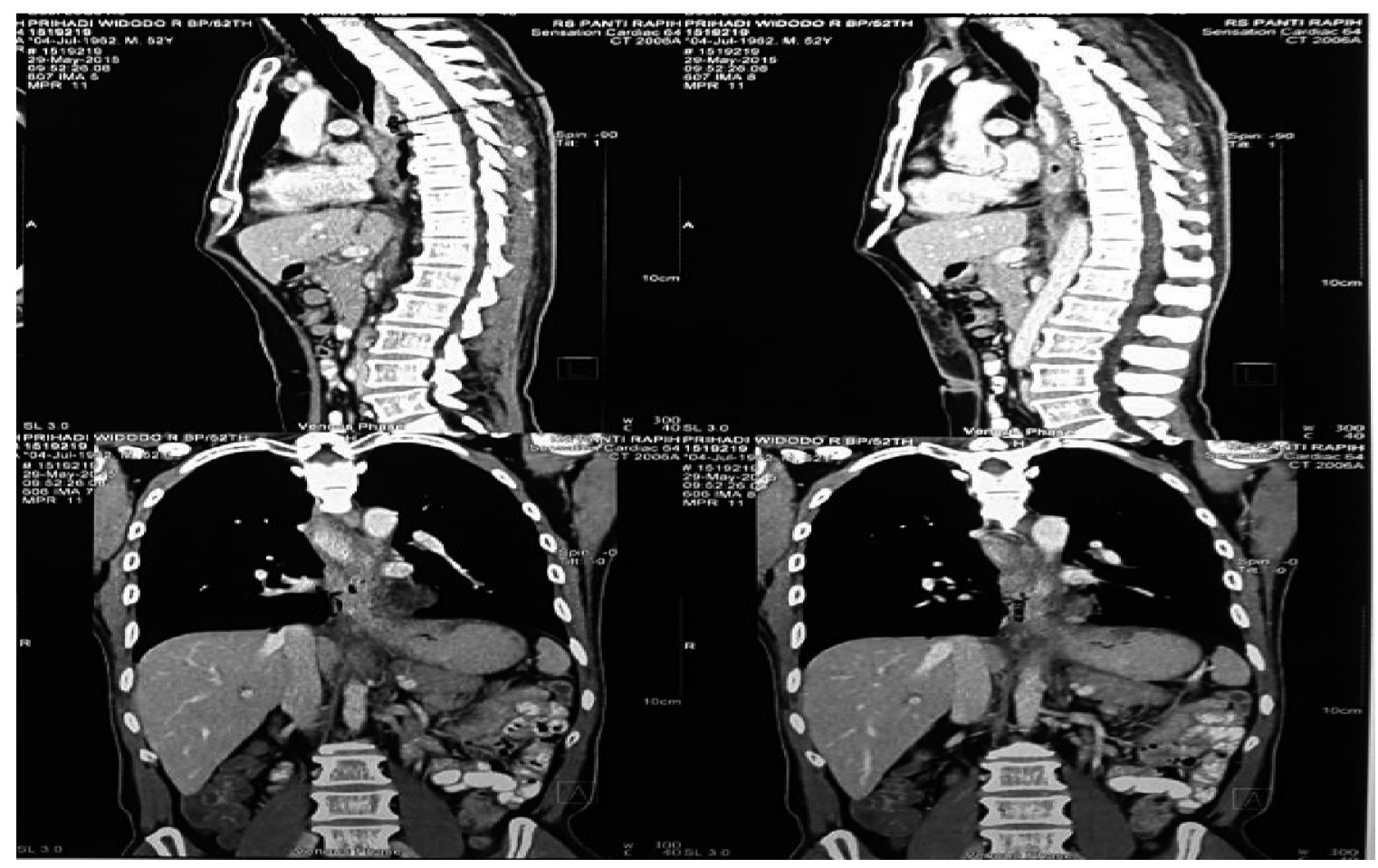

FIGURE 2. First CT scan (29 Mei 2015) showed narrowing of esophagus on the level of 7th thoracic vertebra. 


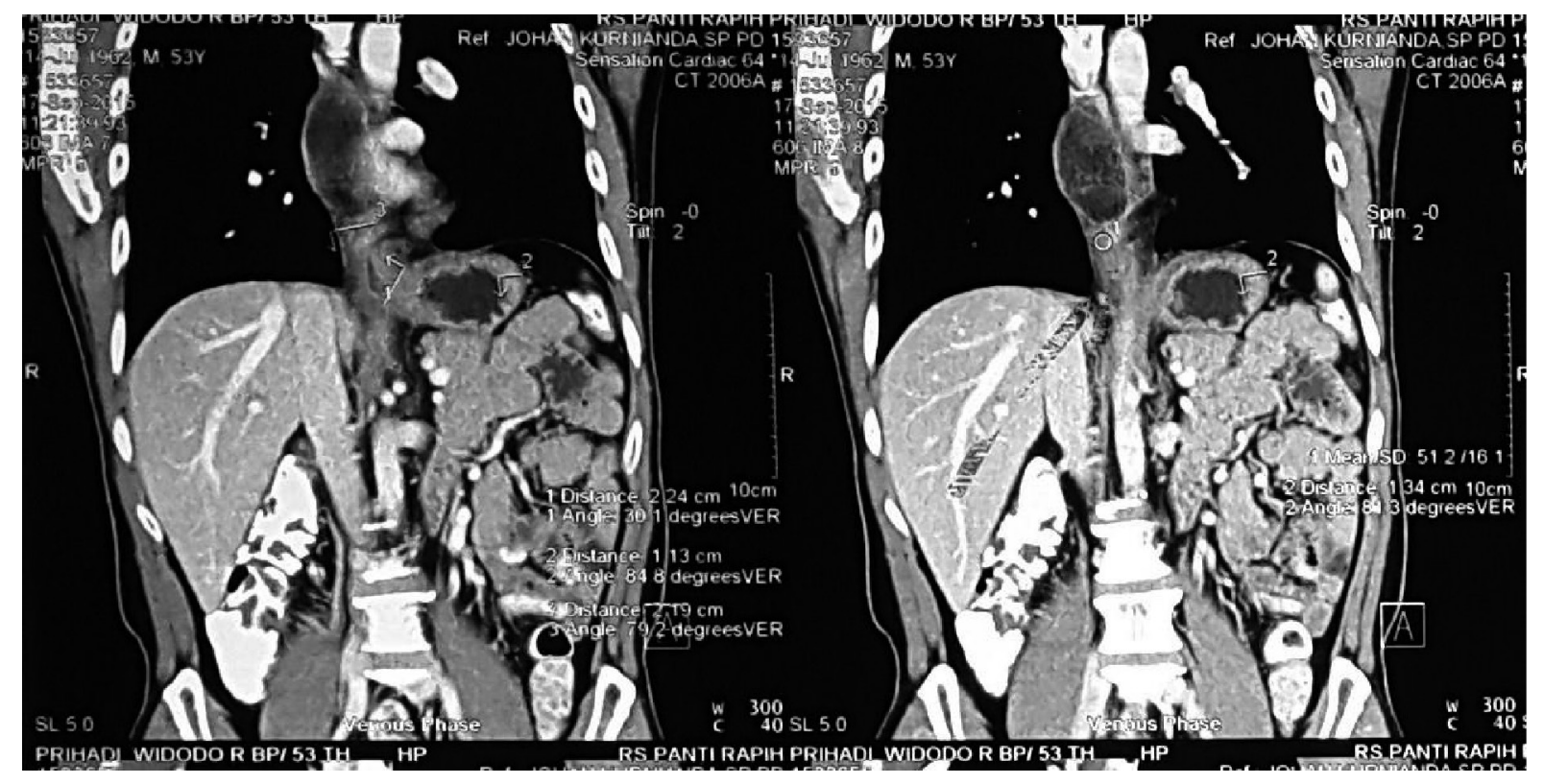

FIGURE 3. Second CT scan (17 September 2015), CT coronal view showed intraluminal tumor of esophagus causing total obstruction on the level of 9 th thoracic vertebra.

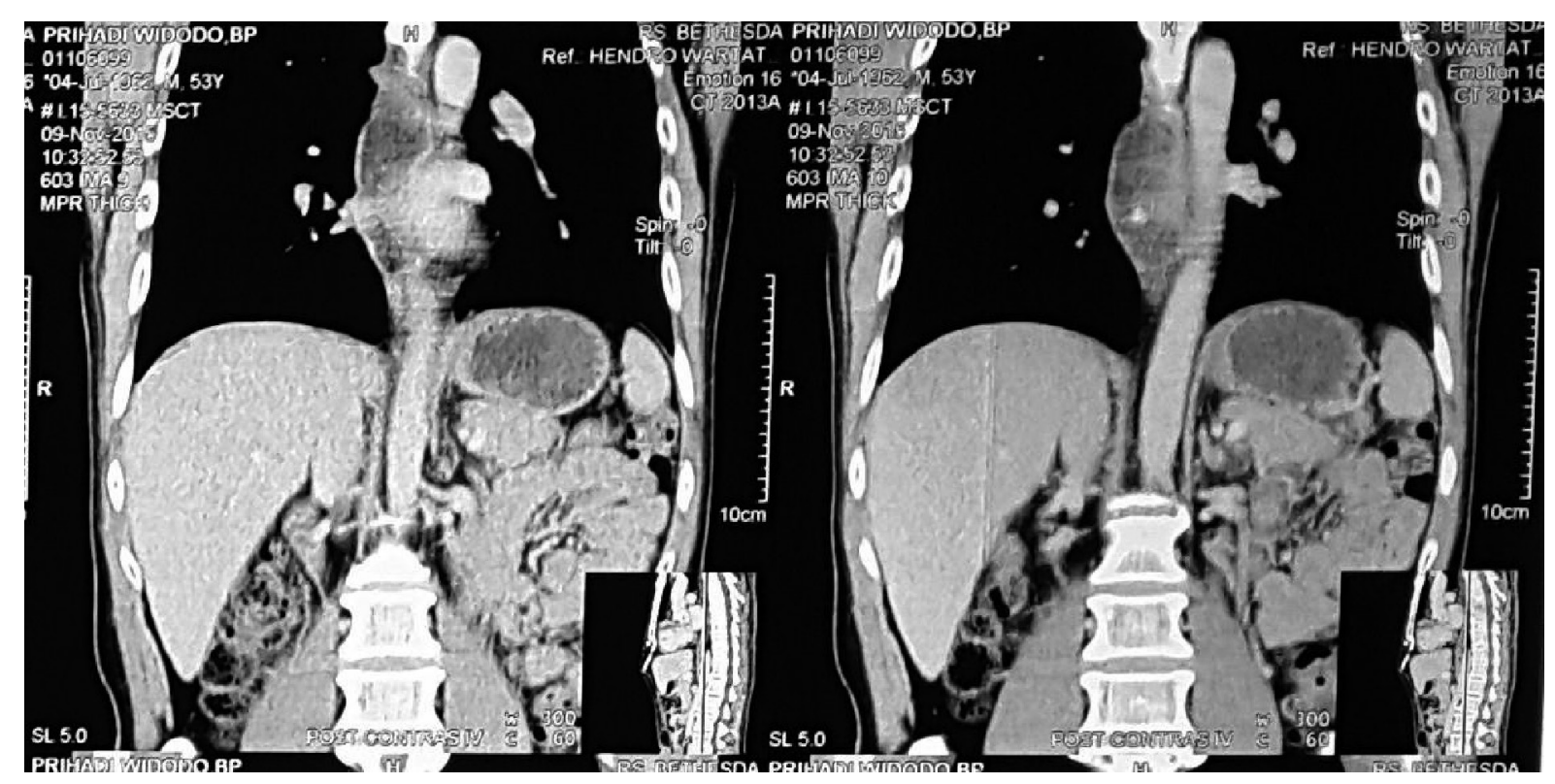

FIGURE 4. Third CT scan (9 November 2015), CT coronal view showed decreasing of the intraluminal tumor dimension.

On 17 December 2015, he underwent laparotomy, thoracotomy, intraoperative endoscopy, resection and anastomosis of esophagus. Tumor mass was not found during the procedure, there was fibrotic tissue around esophagus and esophagogastric junction. Intraoperative endoscopy found stenosis of esophagus. Partial esophagectomy and gastrectomy was done, followed by gastroesophageal anastomosis using stapler CDH25. 
Patient clinical appearance following the procedure was better than before.

Post-operative anatomic pathology evaluation revealed adenocarcinoma with clean border. PET scan and tumor marker assay were planned as follow-up plan. Multimodality approach (chemotherapy and surgery) to management esophageal cancer gave a good outcome in this case.

\section{DISCUSSION}

Tumor or esophageal cancer has a high mortality rate and also known as "silent cancer" due to unspecific symptoms of an early stage of cancer and results in delayed diagnosis. Esophageal cancer is often to be found in 50-60 years old patient. Dysphagia and weight loss are the most reported symptoms in as much as $90 \%$ of the total case. The dysphagia is reported to be progressive, from difficult to ingest solid diet to liquid diet due to obstruction caused by cancer. Other symptoms are odynophagia, hoarseness, coughing, chest pain, and melena. Lymph node involvement is found in more than $75 \%$ cases. Physical examination in esophageal cancer shows no abnormality, except cervical and supraclavicular lymph nodes enlargement. ${ }^{5,7}$

Radiologic examination may support the esophageal cancer diagnosis. Barium contrast may show filling defect to differ obstruction related dysphagia or neurogenic related dysphagia. Esophagogastroduodenoscopy (EGD) is the easiest way to observe dimension, circumferential and linear spread of the tumor, and may allow biopsy of the tumor. Endoscopic ultrasound (EUS) is a definitive method to establish tumor stage. According to TNM tumor staging of the American Joint Commission on Cancer (AJCC), tumor stage is determined based on invasion depth (T) and lymph node involvement $(\mathrm{N})$. Computed tomography (CT) scan with contrast of chest and abdomen is not so helpful to examine far metastasis compared to fluorodeoxyglucose positron emission tomography (FDG-PET) scan.

According to Guidelines for Clinical and Pathologic Studies on carcinoma of the Esophagus on 2007, the esophagus is divided into 3: proximal, medial, and distal. Proximal part is also known as cervical esophagus (Ce), a short segment located on the median line goes along to posterior of the membranous trachea and anterior of the vertebral column. It ends on the same level as manubrium sternum. Thoracic part $(\mathrm{Te})$ goes down on the anterior of the vertebral column and thoracic aorta through esophageal hiatus of the diaphragm. Thoracic part is divided into: the upper thoracic esophagus (Ut), the middle thoracic esophagus (Mt) and lower thoracic esophagus (Lt). The distal part of the esophagus is also called abdominal esophagus (Ae) which is the shortest part. It goes down from the level of esophageal hiatus to gastric cardia on the level of $11^{\text {th }}$ or $12^{\text {th }}$ thoracic vertebra. Overall, the esophagus is divided into 5 parts: $\mathrm{Ce}<\mathrm{Ut}$, $\mathrm{Mt}, \mathrm{Lt}$, and Ae which is related to esophageal cancer predilection (FIGURE 5). ${ }^{10}$

Histologically, the esophagus consists of 4 main layers: mucosal, submucosal, muscularis propia, and adventitia. There is no serous membrane in esophagus, which makes cancer cell is easier to spread. Stratified epithelia of esophageal mucosal layer consist of 3 compartments: basal layer, supra basal layer (intermedium or prickle layer), and superficial layer. Cells proliferate on basal layer and differentiate when migrating from suprabasal to superficial layer. Submucosal layer contains connective tissue, immune cells, neural cells, vascular tissue, and small mucoid gland. Muscularis propria of proximal esophagus consists of skeletal muscle which gradually change into smooth muscle on distal esophagus. Esophagus is covered by adventitia layer which is an external fibrous layer. ${ }^{6}$ 


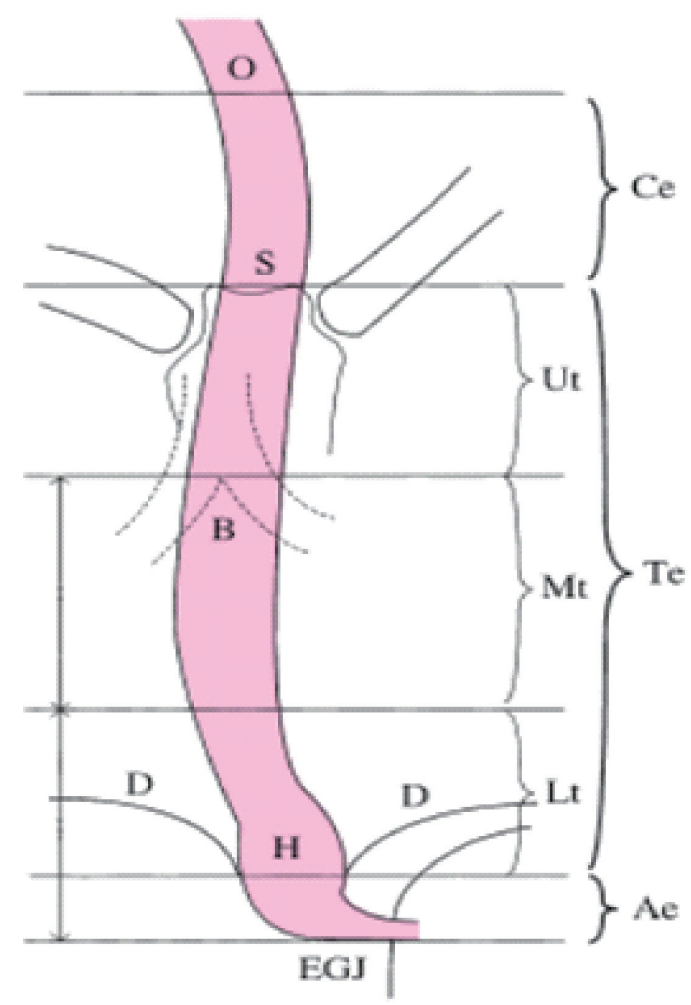

FIGURE 5. Five parts of the esophagus. O: esophageal orifice; S: upper margin of the sternum; B: tracheal bifurcation; D: diaphragm; EGJ: esophagogastric junction; $\mathrm{H}$ : esophageal hiatus. (Guidelines for Clinical and Pathologic Studies on Carcinoma of the Esophagus (9th edition), the Japanese Society for Esophageal Diseases)

Histologically, esophageal cancer mainly divided into 2, squamous cell carcinoma and adenocarcinoma. Less than $1-2 \%$ is sarcoma or small cell carcinoma. Lymphoma, carcinoids, and melanoma is very rare. ${ }^{3}$

Natural history of squamous cell carcinoma and adenocarcinoma of esophagus is different. Squamous cell carcinoma is started from inflammation of squamous epithelial and progressively change to dysplasia and in situ cancer. Adenocarcinoma tends to grow at distal esophagus from columnar-lined metaplastic epithelium which is also known as Barret's esophagus. Gastro esophageal reflux disease (GERD) can damage esophageal surface. Approximately $75 \%$ of all esophageal adenocarcinoma are found at distal esophagus and squamous cell carcinoma is commonly found between middle part and third distal esophagus. ${ }^{1,3}$

Locally advanced esophageal cancer is esophageal cancer which is limited to esophageal or peri-esophageal tissue $(>\mathrm{T} 1, \leq \mathrm{T} 4 \mathrm{a})$ and/or involves lymph nodes (N1-N3), without far metastasis (M0). According to AJCC/TNM staging, tumor which involves pleura, pericardium, or surrounding diaphragm, is resectable (T4a). 
Otherwise, tumor which involves other structures such as aorta, trachea, vertebra, and etc., is unresectable. ${ }^{11}$

Locally advanced tumor is treated using resection surgery since esophagectomy with radical lymphadenectomy is the best choice to achieve local control. ${ }^{8}$ Surgical resection must involve radical, complete, $\mathrm{RO}$, en bloc esophagectomy associated to an extended two-field lymphadenectomy. ${ }^{12}$

However, resection is associated with poor survival rate, metastasis risk, or locoregional recurrence post resection. On locoregional tumor, post resection 5-year survival rate is $10-40 \%$, with a risk of therapeutic failure due to far metastasis. Therefore, it is recommended to use multimodality management on locally advanced cancer which is neoadjuvant therapy or combined chemoradiotherapy (CRT) followed by resection. Some experts prefer definitive CRT to avoid surgical mortality risk. Radiotherapy only has $6 \%$ of 3-year survival rate. Prior study shows chemotherapy for locally advanced esophageal cancer has $45 \%-75 \%$ of response rate. However, it has high relapse rate with poor long-term survival rate. $^{8,13}$
Chemotherapy without radiotherapy before surgery has some advantages such as improvement in dysphagia symptom, better survival rate, disease-free survival before surgery, better control of local tumor or downstaging tumor, better resectability, and chance to eradicate micrometastasis by lowering cancer cell dissemination..$^{8,13}$

Most commonly used chemotherapy regimen is cisplatin and 5-florouracil infusion. Other regimens are bleomycin, vinblastine, carboplatin, etoposide, and paclitaxel. ${ }^{11}$ Although chemotherapy has high advantage, its use is limited by toxicity risk, especially in elderly. The more chemotherapy regimen combination we use, the more toxicity risk increase. ${ }^{14,15}$

Paclitaxel is a taxane anticancer drug. It is commonly used as chemotherapeutic agent in malignancy. It is a microtubule stabilizer that selectively inhibit cell on mitosis phase (M) without interfering synthesis phase (S). it may cause cytotoxicity, depends on administration time and concentration which is radiation sensitizer. ${ }^{16}$ It also has antiangiogenic activity, so that, it is a rational therapy to control cancer progressivity (FIGURE 6). ${ }^{17}$

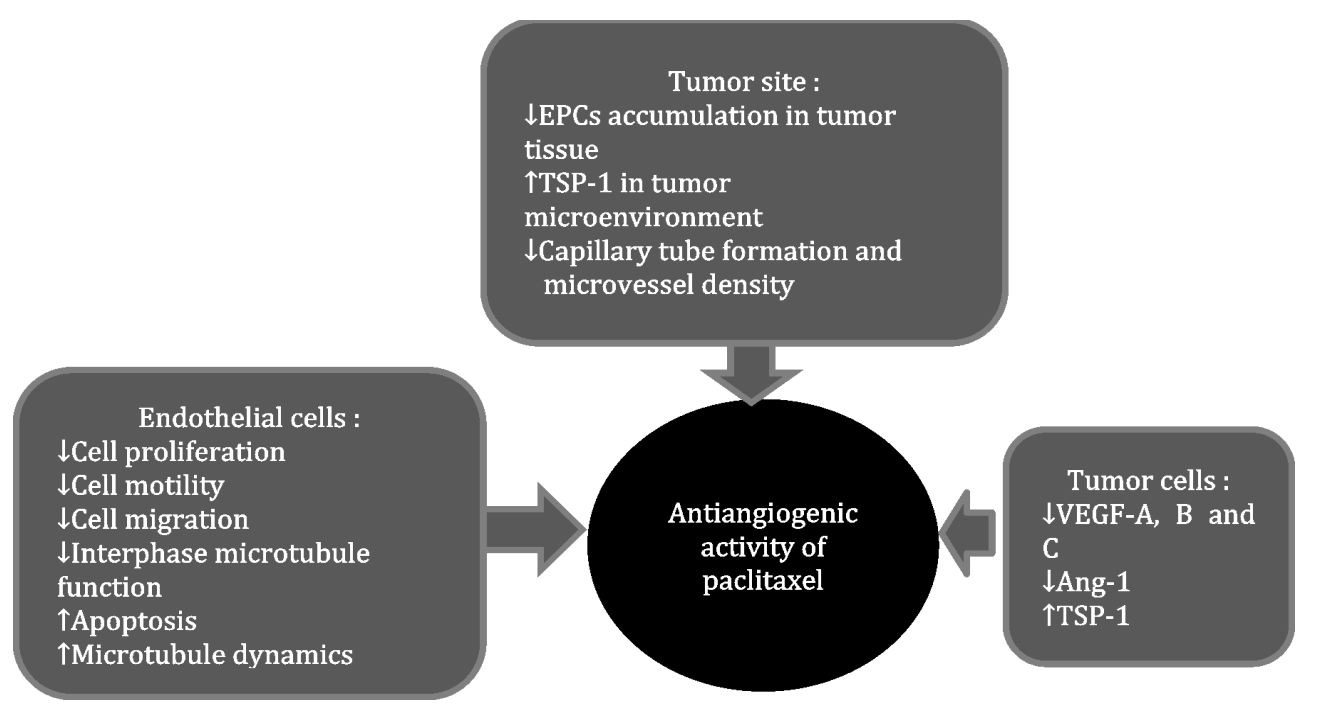

FIGURE 6. Pharmacologic mechanism of paclitaxel antiangiogenic activity. EPC: endothelial progenitor cells; TSP-1: thrombospondin-1; Ang-1: amgiopoetin-1; VEGF: vascular endothelial growth factor.17 


\section{CONCLUSION}

Multimodality management using chemotherapy and surgery gives a good outcome. Chemotherapy given prior to the surgery may decrease the dimension of the tumor, so that tumor resectability will increase. Post-operative anatomic pathology reveals adenocarcinoma with clean border. Post chemotherapy total stenosis is treated by partial esophagectomy and gastrectomy procedures. Esophago-gastric anastomosis using stapler $\mathrm{CDH} 25$ shows a good outcome.

\section{ACKNOWLEDGEMENT}

We would like to thank the patient who has participated in this study.

\section{REFERENCES}

1. Zhang Y. Epidemiology of esophageal cancer. World J Gastroenterol 2013;19 (34): 5597606. https://doi.org/10.3748/wjg.v19.i34.5598

2. Surveillance, Epidemiology, and End Result Program Turning. SEER Stat Fact Sheet: Esophageal Cancer. Retrieved December 26, 2015. Available from URL: http://seer.cancer. gov/statfacts/html/esoph.html

3. Napier KJ, Scheerer M, Mison S. Esophageal cancer: a review of epidemiology, pathogenesis, staging workup and treatment modalities. World J Gastrointest Oncol. 2014; 6(5): 11220. https://doi.org/10.4251/wjgo.v6.i5.112

4. Pennathur A, Gibson MK, Jobe BA, Luketich JD. Oesophageal carcinoma. Lancet 2013; 381: 400-12. https://doi.org/10.1016/S01406736(12)60643-6

5. Lin SH, Chang JY. Esophageal cancer: diagnosis and management. Chin J Cancer 2010; 29(10):843-54. https://doi.org/10.5732/ cjc. 010.10151

6. Tétreault M. Esophageal cancer: insights from mouse models. Cancer Growth and Metastasis.
2015; 8(S1): 37-46. https://doi.org/10.4137/ CGM.S21218

7. Cho JW, Choi SC, Jang JY, Shin SK, Choi $\mathrm{KD}$, Lee $\mathrm{JH}$, et al. Lymph node metastases in esophageal carcinoma: an endoscopist's view. Clin Endosc 2014; 47:523-9. https://doi. org/10.5946/ce.2014.47.6.523

8. D'Journo XB, Thomas PA. Current management of esophageal cancer. J Thoracic Dis 2014; 6 (S2): S253-64.

9. Moore KL, Dalley AF, Agur AMR. Clinically Oriented Anatomy, $6^{\text {th }}$ ed. Baltimore: Lippincott William \& Wilkins, 2010.

10. Takubo K. Pathology of the esophagus: an atlas and textbook, $2^{\text {nd }}$ ed. Hongkong: Springer Publishing, 2007.

11. Keditsu KK, Jiwnani S, Karimundackal G, Pramesh CS. Multimodality management of esophageal cancer. Indian J Surg Oncol 2013;4(2):96-104. https://doi.org/10.1007/ s13193-013-0216-0

12. Low DE. Evolution in surgical management of esophageal cancer. Dig Dis 2013; 31:21-9. https://doi.org/10.1159/000343650

13. Shah RD, Cassano AD, Neifeld JP. Neoadjuvant therapy for esophageal cancer. World J Gastrointest Oncol 2014;6(10):403-6.

14. Kothari N, Almhanna K. Current status of novel agents in advanced gastroesophageal adenocarcinoma. J Gastrointest Oncol 2015;6(1):60-74.

15. Balducci L. Systemic treatment of gastric snd esophageal adenocarcinoma in elderly patients. J Gastrointest Oncol 2015;6(1):75-8.

16. Barbuti AN, Chen Z. Paclitaxel through the ages of anticancer therapy: exploring its role in chemoresistance and radiation therapy. Cancers 2015;7:2360-71. https://doi. org/10.3390/cancers 7040897

17. Bocci G, Di Paolo A, Danesi R. The pharmacological bases of the antiangiogenic activity of paclitaxel. Angiogenesis 2013; 16: 481-92. 